\title{
A Critical Analysis of the Environmental Dossiers from the OECD Sponsorship Programme for the Testing of Manufactured Nanomaterials
}

Hansen, Steffen Foss; Hjorth, Rune; Skjolding, Lars Michael; Bowman, Diana M.; Maynard, Andrew; Baun, Anders

\section{Published in:}

Environmental Science: Nano

Link to article, DOI:

10.1039/C6EN00465B

Publication date:

2017

Document Version

Peer reviewed version

Link back to DTU Orbit

Citation (APA):

Hansen, S. F., Hjorth, R., Skjolding, L. M., Bowman, D. M., Maynard, A., \& Baun, A. (2017). A Critical Analysis of the Environmental Dossiers from the OECD Sponsorship Programme for the Testing of Manufactured

Nanomaterials. Environmental Science: Nano, 4(2), 282-291. https://doi.org/10.1039/C6EN00465B

\section{General rights}

Copyright and moral rights for the publications made accessible in the public portal are retained by the authors and/or other copyright owners and it is a condition of accessing publications that users recognise and abide by the legal requirements associated with these rights.

- Users may download and print one copy of any publication from the public portal for the purpose of private study or research.

- You may not further distribute the material or use it for any profit-making activity or commercial gain

- You may freely distribute the URL identifying the publication in the public portal 


\section{Environmental Science \\ Nano}

\section{Accepted Manuscript}

This article can be cited before page numbers have been issued, to do this please use: S. Foss Hansen, R. Hjorth, L. M. Skjolding, D. Bowman, A. D. Maynard and A. Baun, Environ. Sci.: Nano, 2016, DOI:

10.1039/C6EN00465B.

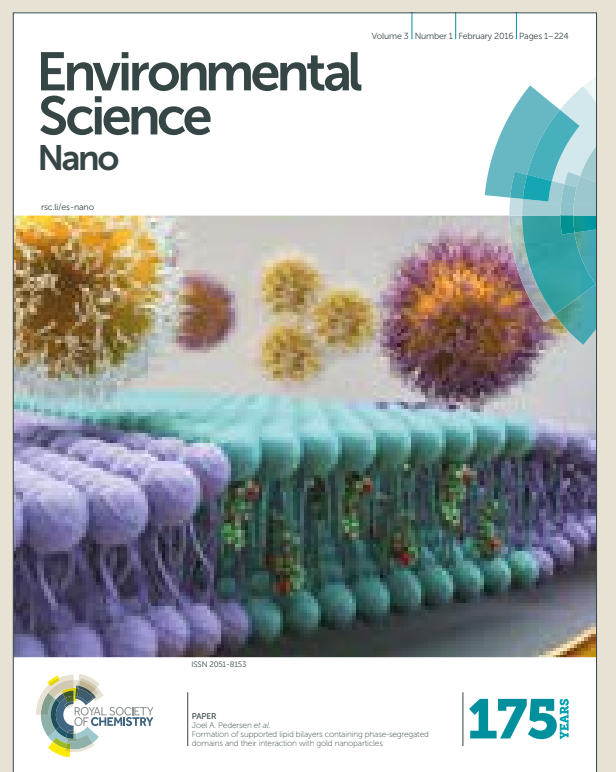

This is an Accepted Manuscript, which has been through the Royal Society of Chemistry peer review process and has been accepted for publication.

Accepted Manuscripts are published online shortly after acceptance, before technical editing, formatting and proof reading. Using this free service, authors can make their results available to the community, in citable form, before we publish the edited article. We will replace this Accepted Manuscript with the edited and formatted Advance Article as soon as it is available.

You can find more information about Accepted Manuscripts in the author guidelines.

Please note that technical editing may introduce minor changes to the text and/or graphics, which may alter content. The journal's standard Terms \& Conditions and the ethical guidelines, outlined in our author and reviewer resource centre, still apply. In no event shall the Royal Society of Chemistry be held responsible for any errors or omissions in this Accepted Manuscript or any consequences arising from the use of any information it contains. 


\section{Environmental Significance Statement}

In 2015, the OECD Working Party on Manufactured Nanomaterials published their long-awaited dossiers on selected nanomaterials. The dossiers are the results of the OECD seven-year sponsorship testing programme for manufactured nanomaterials and the findings, as set out by the OECD, have the potential to influence national policy and risk assessment practices. In this article, we present the first in-depth analysis of the published OECD dossiers with regards to data on physical and chemical properties, environmental fate and ecotoxicology. 


\title{
A Critical Analysis of the Environmental Dossiers from the OECD Sponsorship Programme for the Testing of Manufactured Nanomaterials
}

Steffen Foss Hansen, Rune Hjorth, Lars Michael Skjolding, Diana M. Bowman, Andrew Maynard, Anders Baun

\begin{abstract}
In 2015, the OECD finally published the findings of its seven year testing programme for manufactured nanomaterials. Here, we present the first in-depth analysis of the published OECD dossiers with regards to data on physical and chemical properties, environmental fate and ecotoxicology. Each individual study in the dossiers was reviewed with regard to, among other, which OECD Test Guidelines (TG) were used, and the reliability assigned to the study. We furthermore analyzed in detail the suspension methods used, how media quality was quantified and physical and chemical characterization performed prior, during and/or at the end of the study. We find that the information in the dossiers present an incomplete portfolio of nanomaterial ecotoxicological evaluations that are difficult to draw substantive conclusions from and that most of the studies were not designed to investigate the validity of the OECD Test Guidelines. We acknowledge the effort of the OECD WPMN and recommend that a follow-on program is established with well-defined goals, end-points and direct funding to qualified research laboratories to ensure valid, rigorous, reproducible and efficient research.
\end{abstract}

\section{Introduction}


"I think the public should feel confident that we now better know how to assess the safety of nanomaterials"

- Bob Diderich

On June 9 2015, Bob Diderich, Head of the Organisation for Economic Co-operation and Development (OECD) Environmental Health and Safety Division issued a press release summarizing the key findings of its seven year testing programme for manufactured nanomaterials. With the title headed "OECD chemical studies show way forward for nanomaterial safety", the onepage document provided a high-level overview of activities undertaken under the program. ${ }^{1}$

A key finding, according to this press release, is that the test guidelines used for regular chemical substances are, in the most cases, suitable for use on nanomaterials and that the test guidelines now provide a clear framework for OECD member countries, and others, to move forward in the examination of nanomaterials. ${ }^{1-3}$ These conclusions have subsequently been repeated by Rasmussen et al. $^{3}$, who as members of the OECD Working Party on Manufactured Nanomaterials (WPMN), representing the European Commission's Joint Research Centre (EC JRC), the OECD and the United States (US) Environmental Protection Agency, presented a scientific review of the OECD achievements; the review did not disclose the actual findings According to a press release by the EC JRC following the publication of the dossiers, "The released information contributes to a dramatic shift "in the world's understanding of the properties and applications of nanomaterials ${ }^{\prime \prime \prime} .4$ Should this be true, considering the large number of member states and stakeholders involved in the OECD WPMN, the findings, as set out by the OECD, have the potential to influence national policy and risk assessment practices. As such, there is a need to critically evaluate the OECD dossiers and the conclusions drawn from them. 
Here, we present our analysis of the published OECD dossiers with regards to data on physical and chemical properties, environmental fate and ecotoxicology. Each individual study in the dossiers was reviewed with regard to which OECD Test Guidelines (TG) were used, the reliability assigned to the study, whether Good Laboratory Practice (GLP) was followed, and whether the study had been reported in scientific literature. We furthermore analyzed in details provided about the suspension methods used, how media quality was quantified and physical and chemical characterization performed prior, during and/or at the end of the study. In this assessment we limited ourselves to environmentally-relevant dimensions of the dossiers, on the assumption that these dimensions would provide a robust evaluation of the program. It is furthermore very important to note that this analysis focusses on the dossiers published as part of the OECD Sponsorship Programme and that our analysis does not include an evaluation of other OECD activities e.g. workshops, reports, etc. that have come out of the programme in recent years. Before presenting our findings, we provide a short introduction of the OECD Sponsorship Programme and perceptions of the programme among key stakeholders.

\section{OECD Sponsorship Programme and the perception of the Programme}

When the OECD Sponsorship Programme was originally launched in 2007 it aimed to 1) “...develop and agree on a priority list of representative manufactured nanomaterials [...] for inclusion in a set of reference materials to support measurement, toxicology and risk assessment of nanomaterials" and 2) "...develop a programme to create an understanding of the kind of information on intrinsic properties that may be relevant for exposure and effects assessment of nanomaterials by testing representative nanomaterials for human health and environmental effects as well as environmental fate for a specified set of endpoints (including e.g. specific physicochemical properties, ecotoxicity)". ${ }^{5}$ The programme consisted of two distinct phases. 
In Phase 1, individual entities, such as members of the OECD Working Party on Manufactured Nanomaterials (WPMN) e.g. US, Japan, Germany and the Business and Industry Advisory Committee to the OECD (BIAC) termed "sponsors" had to prepare a Dossier Development Plan for the testing of one or more nanomaterials. The aim was to provide a dataset on more than 50 endpoints related to physical and chemical properties and material characterization; environmental fate; environmental toxicology; mammalian toxicology; and material safety. In Phase 2, additional endpoints were to be generated if deemed necessary by the sponsors of the nanomaterial to gain an understanding of the hazard potential of the respective nanomaterial so that "the resulting data developed in Phase 2 are relevant to risk management purposes". ${ }^{6}$ According to the $\mathrm{OECD}^{6}$, "[t] he combined data provided by Phase 1 and Phase 2 testing will allow, but not necessarily be entirely sufficient for, application to risk assessment paradigms as considered for specific sponsored MN [manufactured nanomaterial] applications..."

The sponsorship programme originally covered 14 "representative" nanomaterials considered to provide a snapshot in time, of nanomaterials in commerce or likely to enter into commerce in the near term. ${ }^{5}$ The scope of the testing included physico-chemical properties, environmental degradation and accumulation, environmental toxicology, and mammalian toxicology. OECD member countries and other stakeholders involved in the actual testing of the individual nanomaterials were furthermore to include information on the materials to be tested as well as information on sample preparation and dosimetry. ${ }^{2,5}$

As of April 2016, eleven dossiers had been published. All the dossiers carry the following disclaimer: "The dossiers [...] are for information only and are not to be used as a reference, standard or validation regarding the safety of specific nanomaterials" and that they were "...chosen to show the efficacy and accuracy of standard test guidelines and was not intended for use in the determination of risks associated with the use or application of nanomaterials. The data contained 
within these dossiers is raw data and has not been evaluated by either the programme sponsors or the WPMN. Any conclusions found within these dossiers are the responsibility of the researchers who made them". 7

These disclaimers, coupled with the strong warning against drawing any conclusion about the risk of nanomaterials, raise the question of whether the purpose of the program had been changed from the initial one of addressing the potential risk of manufactured nanomaterials to "testing the tests".

Intent to "test the tests" is a fully legitimate objective. Yet it does not sit comfortably with the headline under which the results of the OECD Sponsorship Programme were published: "OECD chemical studies show way forward for nanomaterial safety". This clearly indicates that the results were concerned with the safety of nanomaterials, even though the disclaimer clearly specifies that the results cannot be used for this purpose.

A preliminary analysis of the sponsorship programme was completed by the OECD in 2012, at which time it was concluded "test methods used to assess traditional chemicals can be used to determine the safety of nanomaterials, but may have to be adapted to the specificities of nanomaterials" ${ }^{\text {. }}$. Based on the preliminary conclusion by OECD, the European Council for the Chemical Industry (Cefic) publicly stated that: "the OECD conclusion that there is no 'nano effect' is consistent with our understanding" and argued that there is no need for new nanomaterial-specific legislation in Europe. ${ }^{9}$ Cefic is a member of BIAC, who sponsored the dossiers on cerium oxide $\left(\mathrm{CeO}_{2}\right)$, titanium oxide $\left(\mathrm{TiO}_{2}\right)$ and nanoclays, and contributed to all the other dossiers except for the one on dendrimers. ${ }^{7}, 10$

This disconnect has been similarly highlighted in the way in which the Nanotechnology Industries Association (NIA), an active contributor to the nanosilver (Ag) dossier, view the program. The NIA has, for example, repeatedly referred to the OECD Sponsorship Programme in 
public debates to be about nanomaterial safety and regulation. ${ }^{11}$ For instance, in a 2011 discussion specifically related to nanosilver, the NIA argued that "[t]he work of the OECD... is important...because it will answer stakeholder questions in a globally coordinated fashion and provide reliable performance standards for the nanotechnology industries" and "...nanosilver is described [in their input to the OECD programme] as relevant for use in measurement and testing studies, such as for hazard identification, related to the safety of nanomaterials". ${ }^{12}$ These statements appear to be in stark contrast to the views expressed by the OECD itself.

Besides the OECD and some of the industry stakeholders, the only other vocal party involved in the OECD Sponsorship Programme has been the EC JRC; it would seem that very little has been said publically by the member countries themselves.

Following the publication of the dossiers, the EC JRC praised their own contribution to the Sponsorship Programme in a press release calling it a “...major OECD breakthrough on nanomaterials safety knowledge" stating that "The programme... had the objective to ensure that the approaches for assessment of hazard, exposure and risk for manufactured nanomaterials "are of a high quality, science-based and internationally harmonized." ${ }^{44}$ Having co-chaired the steering group coordinating the Sponsorship Programme and having actively contributed to the testing of, for example, silicon dioxide, the EC JRC's contribution the Sponsorship Programme cannot be underestimated. Especially considering the EC JRC has furthermore coordinated the assessment of the applicability and development of OECD test guidelines to nanomaterials in the programme as well as setting priorities and formulating work plans for upgrading existing or developing new OECD Test Guidelines. ${ }^{4}$

Non-governmental organizations have generally been quiet about the Sponsorship Programme. In a joint call for a so-called "Nanopatch" for regulation of nanomaterials in the EU, the three NGOs, Climate Earth, CIEL, and Bund noted that the OECD has concluded that the test 
approaches and guidelines used to regular chemicals was generally appropriate for nanomaterials and pointing out that the test will have to be carried out on the nanoform even in cases where the test guidances does not need to be adapted. ${ }^{13}$

\section{Dossier data overview}

The results of the Sponsorship Programme have been published in the form of 11 dossiers, each containing multiple parts. ${ }^{14}$ The dossier on Ag nanoparticles, for example, is comprised of seven parts and runs to 1752 pages. ${ }^{15}$ According to the OECD the published dossiers collectively involve the results of more than 780 studies across 110 chemical tests and 14 different endpoint categories such as physical and chemical properties and ecotoxicological information. ${ }^{16}$ Each of the endpoint categories entails a number of endpoints (see Table 1). 
Table 1: Number of endpoints reported on across nanomaterials according to the OECD. ${ }^{16} \%$ of total number of endpoint in brackets.

\begin{tabular}{|c|c|c|c|c|c|c|c|c|c|c|c|c|c|c|c|c|c|c|c|c|c|c|}
\hline 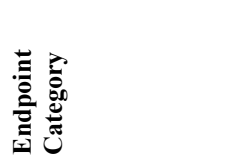 & 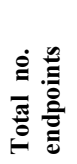 & 8 & $\begin{array}{l}\hat{⿱}_{0}^{n} \\
3 \\
\vdots\end{array}$ & $\begin{array}{l}n \\
\vdots \\
z\end{array}$ & $\stackrel{00}{<}$ & 8 & 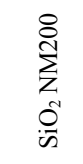 & 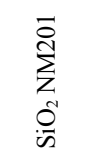 & 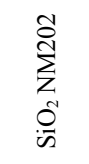 & 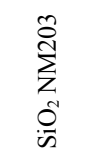 & 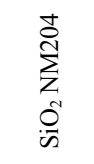 & 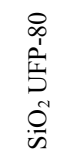 & 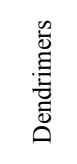 & 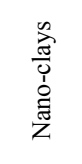 & $\bar{z}$ & 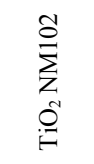 & 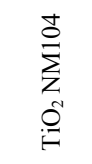 & 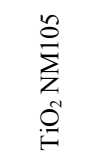 & $\underset{\substack{\infty \\
O}}{\stackrel{8}{Z}}$ & 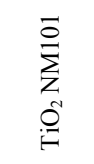 & 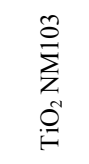 & O \\
\hline $\begin{array}{l}\text { 1. General } \\
\text { information }\end{array}$ & 9 & $\begin{array}{c}2 \\
(22)\end{array}$ & $\begin{array}{c}3 \\
(33)\end{array}$ & $\begin{array}{c}3 \\
(33)\end{array}$ & $\begin{array}{c}2 \\
(22)\end{array}$ & $\begin{array}{c}2 \\
(22)\end{array}$ & $\begin{array}{c}2 \\
(22)\end{array}$ & $\begin{array}{c}2 \\
(22)\end{array}$ & $\begin{array}{c}2 \\
(22)\end{array}$ & $\begin{array}{c}2 \\
(22)\end{array}$ & $\begin{array}{c}1 \\
(11)\end{array}$ & $\begin{array}{c}1 \\
(11)\end{array}$ & - & $\begin{array}{l}2 \\
(22)\end{array}$ & - & $\begin{array}{c}1 \\
(11)\end{array}$ & $\begin{array}{c}2 \\
(22)\end{array}$ & $\begin{array}{c}2 \\
(22)\end{array}$ & $\begin{array}{c}1 \\
(11)\end{array}$ & $\begin{array}{c}2 \\
(22)\end{array}$ & $\begin{array}{c}2 \\
(22)\end{array}$ & $\begin{array}{c}2 \\
(22)\end{array}$ \\
\hline $\begin{array}{l}\text { 2. Classification, la- } \\
\text { belling, PBT assess. }\end{array}$ & 3 & - & - & - & - & $\begin{array}{c}1 \\
(33)\end{array}$ & - & - & - & - & - & - & - & $\begin{array}{c}1 \\
(33)\end{array}$ & - & - & - & - & - & - & - & - \\
\hline $\begin{array}{l}\text { 3. Manufacture, use } \\
\text { and exposure }\end{array}$ & 10 & $\begin{array}{c}1 \\
(10)\end{array}$ & $\begin{array}{c}1 \\
(10)\end{array}$ & $\begin{array}{c}1 \\
(10)\end{array}$ & $\begin{array}{c}5 \\
(50)\end{array}$ & - & - & - & - & - & - & - & - & - & - & - & $\begin{array}{c}1 \\
(10)\end{array}$ & $\begin{array}{c}2 \\
(20)\end{array}$ & - & $\begin{array}{c}1 \\
(10)\end{array}$ & $\begin{array}{c}2 \\
(20)\end{array}$ & - \\
\hline $\begin{array}{l}\text { 4. Physical and } \\
\text { chemical properties }\end{array}$ & 37 & $\begin{array}{c}17 \\
(46)\end{array}$ & $\begin{array}{l}10 \\
(27)\end{array}$ & $\begin{array}{l}12 \\
(32)\end{array}$ & $\begin{array}{c}19 \\
(51)\end{array}$ & $\begin{array}{l}17 \\
(46)\end{array}$ & $\begin{array}{c}19 \\
(51)\end{array}$ & $\begin{array}{l}18 \\
(49)\end{array}$ & $\begin{array}{l}17 \\
(46)\end{array}$ & $\begin{array}{c}18 \\
(49)\end{array}$ & $6(16)$ & $\begin{array}{c}0 \\
(0)\end{array}$ & $\begin{array}{c}10 \\
(27)\end{array}$ & $\begin{array}{c}5 \\
(14)\end{array}$ & $\begin{array}{c}8 \\
(22)\end{array}$ & $8(22)$ & $\begin{array}{l}24 \\
(65)\end{array}$ & $\begin{array}{l}25 \\
(68)\end{array}$ & $8(22)$ & $\begin{array}{l}20 \\
(54)\end{array}$ & $\begin{array}{l}23 \\
(62)\end{array}$ & $\begin{array}{c}17 \\
(46)\end{array}$ \\
\hline $\begin{array}{l}\text { 5. Environmental } \\
\text { fate and pathways }\end{array}$ & 24 & $\begin{array}{c}4 \\
(17)\end{array}$ & $\begin{array}{c}4 \\
(17)\end{array}$ & $\begin{array}{c}1 \\
(4)\end{array}$ & $\begin{array}{c}8 \\
(33)\end{array}$ & $\begin{array}{c}3 \\
(13)\end{array}$ & $\begin{array}{c}1 \\
(4)\end{array}$ & $\begin{array}{c}1 \\
(4)\end{array}$ & $\begin{array}{c}1 \\
(4)\end{array}$ & $\begin{array}{c}1 \\
(4)\end{array}$ & - & - & - & - & - & $\begin{array}{c}2 \\
(8)\end{array}$ & $\begin{array}{c}11 \\
(46)\end{array}$ & $\begin{array}{c}10 \\
(42)\end{array}$ & $\begin{array}{c}1 \\
(4)\end{array}$ & $\begin{array}{c}9 \\
(38)\end{array}$ & $\begin{array}{c}12 \\
(50)\end{array}$ & $\begin{array}{c}2 \\
(8)\end{array}$ \\
\hline $\begin{array}{l}\text { 6. Ecotoxicological } \\
\text { information }\end{array}$ & 20 & $\begin{array}{c}0 \\
(0)\end{array}$ & $\begin{array}{c}9 \\
(45)\end{array}$ & $\begin{array}{c}9 \\
(45)\end{array}$ & $\begin{array}{l}17 \\
(85)\end{array}$ & $\begin{array}{c}2 \\
(10)\end{array}$ & $\begin{array}{c}(7) \\
2 \\
(10)\end{array}$ & $\begin{array}{c}\text { (7) } \\
2 \\
(10)\end{array}$ & $\begin{array}{c}2 \\
2 \\
(10)\end{array}$ & $\begin{array}{c}\text { (7) } \\
2 \\
(10)\end{array}$ & - & - & $\begin{array}{c}5 \\
(25)\end{array}$ & $\begin{array}{c}4 \\
(20)\end{array}$ & $\begin{array}{c}6 \\
(30)\end{array}$ & $\begin{array}{c}\text { (0) } \\
5 \\
(25)\end{array}$ & $\begin{array}{l}13 \\
(65)\end{array}$ & $\begin{array}{l}15 \\
(75)\end{array}$ & $\begin{array}{c}(7) \\
5 \\
(25)\end{array}$ & $\begin{array}{l}14 \\
(70)\end{array}$ & $\begin{array}{l}13 \\
(65)\end{array}$ & $\begin{array}{c}8 \\
(40)\end{array}$ \\
\hline $\begin{array}{l}\text { 7. Toxicological } \\
\text { information }\end{array}$ & 40 & $\begin{array}{c}9 \\
(23)\end{array}$ & $\begin{array}{c}13 \\
(33)\end{array}$ & $\begin{array}{c}16 \\
(40)\end{array}$ & $\begin{array}{c}23 \\
(58)\end{array}$ & $3(8)$ & $\begin{array}{l}10 \\
(25)\end{array}$ & $9(23)$ & $9(23)$ & $9(23)$ & $8(20)$ & $\begin{array}{c}1 \\
(3)\end{array}$ & - & - & $\begin{array}{c}7 \\
(18)\end{array}$ & $4(10)$ & $\begin{array}{c}20 \\
(50)\end{array}$ & $\begin{array}{c}20 \\
(50)\end{array}$ & $3(8)$ & $\begin{array}{c}20 \\
(50)\end{array}$ & $\begin{array}{c}20 \\
(50)\end{array}$ & $\begin{array}{c}15 \\
(38)\end{array}$ \\
\hline $\begin{array}{l}8 \text {. Analytical } \\
\text { methods }\end{array}$ & 1 & - & - & - & - & - & - & - & - & - & - & - & $\begin{array}{c}1 \\
(100)\end{array}$ & - & - & - & - & - & - & - & - & - \\
\hline $\begin{array}{l}\text { 9. Residues in food } \\
\text { and feeding stuffs }\end{array}$ & 10 & - & - & - & - & - & - & - & - & - & - & - & - & - & - & - & - & - & - & - & - & - \\
\hline $\begin{array}{l}\text { 10. Effectiveness } \\
\text { against target org. }\end{array}$ & 2 & - & - & - & - & - & - & - & - & - & - & - & - & - & - & - & - & - & - & - & - & - \\
\hline $\begin{array}{l}\text { 11. Guidance on } \\
\text { safe use }\end{array}$ & 1 & - & - & - & $\begin{array}{c}1^{*} \\
(100)\end{array}$ & - & - & - & - & - & - & - & - & - & - & - & $\begin{array}{c}1^{*} \\
(100)\end{array}$ & $\begin{array}{c}1^{*} \\
(100)\end{array}$ & - & $\begin{array}{c}1^{*} \\
(100)\end{array}$ & $\begin{array}{c}1^{*} \\
(100)\end{array}$ & - \\
\hline $\begin{array}{l}\text { 12. Literature } \\
\text { search }\end{array}$ & 1 & - & - & - & - & - & - & - & - & - & - & - & - & - & - & - & - & - & - & - & - & - \\
\hline $\begin{array}{l}\text { 13. Assessment } \\
\text { reports }\end{array}$ & 1 & - & - & - & - & - & - & - & - & - & - & - & - & - & - & - & - & - & - & - & - & - \\
\hline $\begin{array}{l}\text { 14. Information } \\
\text { requirements }\end{array}$ & 13 & - & - & - & - & - & - & - & - & - & - & - & - & - & - & - & - & - & - & - & - & $\begin{array}{c}1 \\
(8)\end{array}$ \\
\hline Sum & 172 & 33 & 40 & 42 & 75 & 28 & 34 & 32 & 31 & 32 & 15 & 2 & 16 & 12 & 21 & 20 & 72 & 75 & 18 & 67 & 73 & 45 \\
\hline
\end{tabular}

- : No data available in the dossiers

* Information was claimed to been included on Guidance on safe use, but is actually not 
Although 14 endpoint categories were addressed, studies are typically available for only 4-6 endpoint categories for each substance. Although the $\mathrm{OECD}^{6}$ stated that a rationale for not testing must be provided as part of the dossiers, such a rationale is not included in any of the dossiers. In addition, many of the endpoints that "must be addressed", according to $\mathrm{OECD}^{6}$, have not been.

For ecotoxicological information, for instance, the $\mathrm{Ag}$ dossier includes information on $85 \%$ of the endpoints, whereas the $\mathrm{TiO}_{2}$ dossier is reported to have $65-75 \%$ (for more information see Table 1). According to the OECD, no ecotoxicological information is available for $\mathrm{C} 60^{17}$. But our detailed analysis of the dossier of C60 reveals that there are actually two ecotoxicological studies on C60 one study on the short-term toxicity on fish using OECD TG 203 by Shinohara et al. from $2009^{18}$ and one long-term toxicity study on fish by Fraser et al. ${ }^{19}$ from 2011.

OECD argues "[m] uch valuable information on the safety of MNs can be derived by testing a representative set for human health and environmental safety". ${ }^{2}$ Yet for the majority of the test reports, the information provided is inadequate to enable an expert in the field to evaluate the validity of the study and the methods used. Many of the tests on physical and chemical properties were done by one contributor and the ecotoxicological testing performed by another contributor independently of each other, further undermining data reliability and interpretability (see for instance the single walled carbon nanotubes (SWCNTs) dossier ${ }^{20}$ ). The lack of comparable tests across multiple laboratories prevents inter-laboratory comparisons, and raises questions as to whether measurements were replicable between different laboratories. Further complicating data interpretation, the SWCNTs and C60 material for which physical and chemical characterization data is available is not always the same as the material used to generate environmental fate and ecotoxicological data. ${ }^{21,22}$ This is despite evidence of variations in nanomaterials that occur between production facilities and production batches. ${ }^{23,24}$ 
For instance, in the case of SWCNTs, physical chemical properties are reported on for Nikkiso SWCNT and Super Growth SWCNT only, whereas data for "Environmental fate and Pathways" (Chapter 5 in the dossiers) are reported on for Nikkiso SWCNT and Super Growth as well as SWCNT US 4 SWCNTs, US CheapTubes, SWeNT SWCNT and US RTI SWCNT. Similarly, ecotoxicological information is provided sporadically for Sigma-Aldrich SWCNT, Cheap Tubes SWCNT, NRC SWCNT, NRC pristine SWCNTs, Shenzhen Nanotech Port SWCNT and Arc-discharge produced SWCNT in addition to Nikkiso SWCNT and Super Growth SWCNT. ${ }^{21}$

The OECD dossiers collectively provide data based on a large range of effect concentrations, but the dossiers tend to replicate data that had been previously generated (see Stone et $a l .{ }^{25}$ ). Of particular note are the effects concentrations on $\mathrm{SiO}_{2}$, which in some cases are much higher $(\geq 1,000 \mathrm{mg} / \mathrm{L})$ than the concentrations $(<10 \mathrm{mg} / \mathrm{L})$ found in scientific studies ${ }^{26}$ on $14 \mathrm{~nm}$ amorphous $\mathrm{SiO}_{2}{ }^{27}$ prior to the launch of the Sponsorship Programme. ${ }^{28}$

\section{Quality of the information in the dossier}

Based on the 11 dossiers, the OECD asserted that the "...programme verifies the testing methods used on Manufactured Nanomaterials"2. Figure 1, Tables 1 and 2 show the number of studies that have been reported for each ecotoxicology-related endpoint. It would be expected that an analysis of test guidelines for nanomaterials would include studies that are explicitly designed to evaluate test guidelines, and that they are of "high quality" from a regulatory perspective ${ }^{29}$, as also noted by the EC JRC in their press release on the publication of the dossiers. ${ }^{4}$

But this is not the case. Table 2 shows the number of studies in the dossiers that have been published in the scientific literature, have been submitted under the REACH regulation, or have been assigned a Klimisch score of 1, 2, 3 or 4 . The assignment of Klimisch scores ${ }^{30}$ is used by the

European Chemical Agency ${ }^{29}$ to communicate the regulatory reliability of a given study when 
evaluating the quality of experimental toxicological and ecotoxicological data. A Klimisch score of 1 means that the study and data is "reliable without restrictions", whereas a score of 2,3 and 4 means that it is "reliable with restriction", "not reliable" and "not assignable", respectively. It is not transparent how the Klimisch scores have been assigned in the dossiers. A close review of the studies suggests that some scores have been assigned by the laboratory performing the tests, others have been assigned by the sponsor(s) of the respective dossiers (e.g., scores have been assigned to papers from the literature, for which the authors of the papers have not assigned any scores themselves), while others have been assigned incorrectly. For example, even though Klimisch scores can be only be assigned to laboratory studies, a score of 1 is assigned to a literature review of $\mathrm{TiO}_{2}$ by US National Institute of Standards and Technology.

More than half of the studies in the dossiers have not been given the highest reliability scores of $1(21 \%)$ or $2(23 \%)$ (see Table 2$)$, which indicates that they are either "not reliable" or that reliability is "not assignable" for risk assessment purposes. Because of this, an analysis of the suitability of the TGs for testing nanomaterials cannot reliably be based on studies assigned with high regulatory reliability scores alone and no claims should therefore be made by the OECD regarding their programme having verified the testing methods used.

Finally, it should be noted that studies that suggest specific adaptations of OECD TGs to make the suitable for testing NMs generally have been assigned a low or no Klimisch score. 
Table 2. Overview of studies reported in REACH, studies published in the scientific literature and number of studies assigned specific reliability scores

\begin{tabular}{|c|c|c|c|c|c|c|c|c|c|c|c|c|c|c|c|c|c|c|c|c|c|}
\hline & 8 & $\begin{array}{l}\tilde{b}^{\infty} \\
\vdots \\
\vdots\end{array}$ & $\begin{array}{l}\stackrel{n}{Z} \\
\vdots \\
\Sigma\end{array}$ & $\stackrel{00}{<}$ & $\begin{array}{l}\delta^{N} \\
U^{2}\end{array}$ & 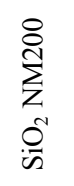 & 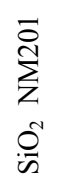 & 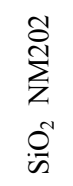 & 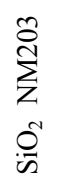 & 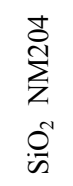 & 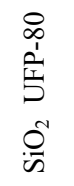 & 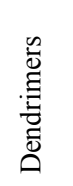 & 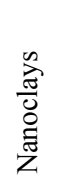 & $\bar{Z}$ & 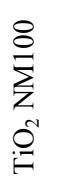 & 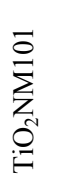 & 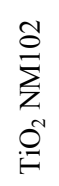 & 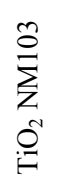 & 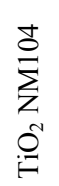 & 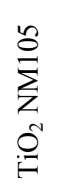 & $\begin{array}{l}\text { o } \\
\text { N }\end{array}$ \\
\hline Studies reported in REACH & & & 5 & & & & & & & & & & & & & & & & & & \\
\hline Studies published in scientific literature & 5 & 11 & & 19 & 1 & & & & & & & 5 & & 1 & & 3 & & & & 41 & 17 \\
\hline GLP studies & & 15 & 16 & 3 & & & 2 & 2 & & & & & & & 1 & 2 & & 1 & & 3 & 4 \\
\hline Reliability score 1 & & 20 & 17 & 3 & & & 1 & 1 & & & & & & & 4 & 5 & 5 & 1 & & 14 & 1 \\
\hline Reliability score 2 & 4 & 4 & 1 & 15 & & & 1 & 1 & & & & & & 5 & 3 & 7 & 1 & 1 & 1 & 28 & 11 \\
\hline Reliability score 3 & & & 1 & & & & & & & & & & & & & & & & & 12 & 3 \\
\hline Reliability score 4 & 5 & 4 & 9 & & & & & & & & & & & & & & & & & & 6 \\
\hline Reliability not assigned & 7 & 4 & & 47 & 8 & & 1 & 1 & & & & 6 & 4 & 1 & 2 & 7 & 3 & 10 & 8 & 39 & \\
\hline
\end{tabular}




\section{Suitability of existing testing guidelines}

Considering all the studies conducted independent of their Klimisch score, the majority of the studies use the OECD TGs without modifications and fails to provide basic information about how the tests were performed, or what was learned during the testing of nanomaterials. It is unclear whether the OECD has interpreted the absence of these comments as confirmation of the applicability of their TGs. ${ }^{1}$ Many studies did not use OECD TGs, but instead used TGs from British Standards, US Environmental Protection Agency and alike. This raises the question of the degree to which a study using TGs other than the OECD TGs is informative about the overall applicability of the OECD TGs for nanomaterials. Several studies furthermore simply state: "no guideline available". For instance, none of the studies on dendrimers use a TG and it is noted that there are "no guideline available" when it comes to short-term toxicity to fish. This is despite the OECD publishing its TG on short-term toxicity to fish in $1998 .{ }^{31}$

A group of studies call for adaptations of the OECD TGs. For $\mathrm{TiO}_{2}$, for instance, authors of one of the studies state that they added particle sizing and reporting of primary particle properties to their study “....as OECD test guidelines do not address these and other nanomaterial specific aquatic testing issues". ${ }^{32}$ They go on to call for additional physical-chemical properties to be reported as part of the TGs that they have used. Others report using altered media with reduced ionic strength and hardness, and call for revisions of the loss acceptable during testing or suggest that a metric other than mass should be explored. ${ }^{20,32-34}$

Finally, a third category of studies call for the discontinued use of the specific TGs that have been applied. For example, for $\mathrm{TiO}_{2}$ nanoparticles the authors of one study conclude "...that the OECD test guideline 106 cannot be employed to derive information on adsorption - desorption isotherms at least for the nanomaterials tested here". ${ }^{34}$ 
Across the three categories of studies illustrated in Figure 1 and in Table 1 and 2, it is difficult to see how the OECD can conclude that the tests were generally found to be suitable for nanomaterials.

\section{Compliance with OECD test recommendations}

In 2010 the OECD published a Guidance Manual for the Testing of Manufactured Nanomaterials to assist sponsors in the Sponsorship programme with the intention "...to ensure that the information collected from this testing programme be reliable, accurate and consistent" ${ }^{\prime 6}$. Based on preliminary findings from the OECD Sponsorship Programme in 2010, and with the intention to guide the continuously implementation and unfolding of the programme, OECD furthermore published a Guidance on Sample Preparation and Dosimetry outlining important considerations that researchers and others should bear in mind in order to obtain meaningful and reproducible test results ${ }^{37}$. The guidance states that, sponsors should be taken into consideration:

1. Method of suspension e.g. stirring, sonication;

2. Quantification of media quality e.g. pH, ionic strength; and

3. Physical-chemical characterization e.g. particle size and/or agglomerate size distribution.

In total, there are 15 items similar to stirring, ionic strength, and size distribution that the OECD recommends documenting when performing ecotoxicity tests of nanomaterials (see column 1 of Table 1). An analysis of the compliance of the available dossiers with the recommendations in the guidance document ${ }^{35}$ is presented in Table 3. 
Table 3. Total number of ecotoxicity studies available in the OECD Sponsorship Programme dossiers and the percentage of these that are in compliance the nanospecific OECD test recommendation.

\begin{tabular}{|c|c|c|c|c|c|c|c|c|c|c|c|c|c|c|c|c|c|c|}
\hline OECD ENV/JM/MO0 (2012)40 & $\stackrel{8}{8}$ & $\begin{array}{l}\text { 艺 } \\
\text { 品 }\end{array}$ & $\begin{array}{l}\text { 吕 } \\
\sum\end{array}$ & $\stackrel{\infty}{<}$ & ర̊ & 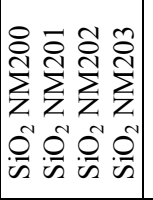 & 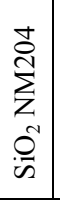 & 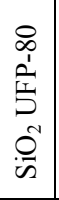 & 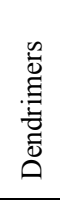 & 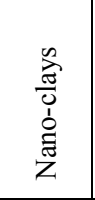 & 齐 & 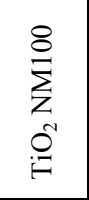 & $\begin{array}{l}\bar{O} \\
\sum_{Z} \\
0 \\
0\end{array}$ & 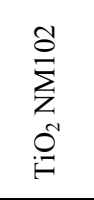 & 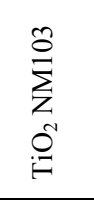 & 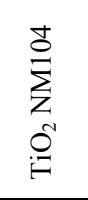 & 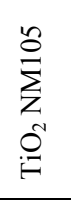 & 요 \\
\hline Total number of ecotoxicological studies & 2 & 30 & 23 & 42 & 4 & 2 & & & 6 & 4 & 8 & 8 & 14 & 6 & 6 & 5 & 67 & 21 \\
\hline \multicolumn{19}{|l|}{ Method of suspension } \\
\hline Method of suspension & $50 \%$ & $60 \%$ & $30 \%$ & $62 \%$ & $25 \%$ & $100 \%$ & & & & $25 \%$ & & $100 \%$ & $93 \%$ & $100 \%$ & $100 \%$ & $100 \%$ & $84 \%$ & $43 \%$ \\
\hline Suspension media & $100 \%$ & $77 \%$ & $35 \%$ & $62 \%$ & $100 \%$ & $100 \%$ & & & & $100 \%$ & $13 \%$ & $100 \%$ & $93 \%$ & $100 \%$ & $100 \%$ & $100 \%$ & $72 \%$ & $67 \%$ \\
\hline \multicolumn{19}{|l|}{ Quantification/control of potentially altered toxicity? } \\
\hline \multicolumn{19}{|l|}{ Quantification of media quality } \\
\hline $\mathrm{pH}$ & $50 \%$ & $43 \%$ & $35 \%$ & $12 \%$ & $75 \%$ & $100 \%$ & & & & $100 \%$ & & $50 \%$ & $57 \%$ & $67 \%$ & $67 \%$ & $60 \%$ & $25 \%$ & $76 \%$ \\
\hline DOM & & $3 \%$ & & $7 \%$ & & & & & & $25 \%$ & & & & & & & $4 \%$ & \\
\hline Ionic strength & & & & $7 \%$ & & & & & & & & & & & & & & $48 \%$ \\
\hline \multicolumn{19}{|l|}{ Determinations made at intervals in the stock solution } \\
\hline Determinations made at intervals in the test media & & & $4 \%$ & & & & & & & & & & & & & & & \\
\hline \multicolumn{19}{|l|}{ Physical-chemical characterization } \\
\hline Characterisation made of (dry) particles & $50 \%$ & $47 \%$ & $17 \%$ & & $100 \%$ & $100 \%$ & & & $6 \%$ & $100 \%$ & & $100 \%$ & $93 \%$ & $100 \%$ & $100 \%$ & $100 \%$ & $48 \%$ & $57 \%$ \\
\hline Characterisation made in actual test media & & & & $33 \%$ & & & & & & $50 \%$ & & & & & & & & $24 \%$ \\
\hline Characterisation made in stock solution & & & & $5 \%$ & & & & & & & $25 \%$ & & & & & & & $24 \%$ \\
\hline Characterisation made in presence of test organisms? & & & & & & & & & & $25 \%$ & & & & & & & & \\
\hline $\begin{array}{l}\text { Particle/agglomeration size distribution and material } \\
\text { concentration assessed at intervals? }\end{array}$ & & & & $31 \%$ & & & & & & $75 \%$ & $13 \%$ & $13 \%$ & $14 \%$ & & & & $12 \%$ & \\
\hline $\begin{array}{l}\text { Particle/aggregate/agglomeration size distribution } \\
\text { measured using two or more methods? }\end{array}$ & & & & $5 \%$ & & & & & & $25 \%$ & & & & & & & $9 \%$ & $19 \%$ \\
\hline $\begin{array}{l}\text { Degradation of nanomaterial investigated? (release of } \\
\text { ions) }\end{array}$ & & & & $19 \%$ & & & & & & & & & & & & & & \\
\hline
\end{tabular}


The dossier for Ag reveals the highest degree of compliance with the nanospecific OECD test recommendations, with 11 of the 15 items being reported on. For most materials, only four of the items were addressed: method of suspension (stirring, sonication, etc.), suspension media (freshwater, saltwater), $\mathrm{pH}$ and characterization made of (dry) particles. The dossiers on dendrimers and the different forms of $\mathrm{SiO}_{2}\left(\mathrm{SiO}_{2} \mathrm{NM} 203, \mathrm{SiO}_{2} \mathrm{NM} 204\right.$ and $\left.\mathrm{SiO}_{2} \mathrm{UFP}-80\right)$ and are noteworthy for their lack of reporting on nanospecific properties and compliance with OECD test recommendations for nanomaterials.

The frequency at which the different items are reported varies greatly. For the dossiers in which most studies on ecotoxicological information are included, i.e. SWCNTs, MWCNTs, Ag, $\mathrm{ZnO}$ and the form of $\mathrm{TiO}_{2}$ termed NM 105, the method of suspension is reported in $60 \%, 30 \%$, $62 \%, 43 \%$ and $84 \%$ of the studies, respectively. For the suspension media the percentages are $77 \%$, $35 \%, 62 \%$ and $67 \%$ and $72 \%$, respectively. Regarding quantification of media quality, $\mathrm{pH}$ is the only parameter that is reported more than once across all the dossiers and it is reported in $30-50 \%$ of the studies, except for two of the $\mathrm{SiO}_{2}$ forms and dendrimers.

For physical-chemical characterization, the characterization made of (dry) particles is the only parameter that was reported on consistently; reporting ranged between $20-100 \%$ depending on the dossier. In contrast, characterization was only carried out in actual test media in half of the studies on nanoclays (50\%), a third of the studies of $\mathrm{Ag}(33 \%)$ and about a fourth of the studies on $\mathrm{ZnO}(24 \%)$. Across all the ecotoxicity tests reported in the dossiers, characterization in the presence of test organisms was only carried out in one study (nanoclays).

Particle/agglomeration size distribution and material concentration assessed at intervals was, in general, not reported. The few exceptions were $\mathrm{Ag}$ (31\%), nanoclays (75\%), $\mathrm{Au}(13 \%), \mathrm{TiO}_{2}$ NM100 (13\%), $\mathrm{TiO}_{2} \mathrm{NM} 101$ (14\%) and $\mathrm{TiO}_{2} \mathrm{NM} 105$ (12\%). This lack of reporting is of concern since aggregation and agglomeration is well known to affect ecotoxicity of nanomaterials, 
especially $\mathrm{TiO}_{2}$. Furthermore, it reveals whether constant exposure concentration can be maintained during testing. This is a fundamental requirement for establishing valid concentration-response relationships used to derive effect concentration values. Despite OECD's recommendations of measuring particle/aggregate/agglomeration size distribution using two or more methods, this was only done in $5 \%, 25 \%, 9 \%$ and $19 \%$ for $\mathrm{Ag}$, nanoclay, $\mathrm{TiO}_{2} \mathrm{NM} 105, \mathrm{ZnO}$, respectively; the dossiers for all other nanomaterials are silent on this.

The dossier for nanoclays seem to be the only one to include characterization in the test media in the presence of the test organism using more methods and where characterization was performed at intervals during the test. Unfortunately, however, the data and results hereof are not presented in the published material. Finally, degradation of nanomaterials (e.g. the release of ions) was only investigated in $19 \%$ of the studies on $\mathrm{Ag}$, despite the fact that ion release is believed to be the main cause of the ecotoxicity of nanosilver. ${ }^{36}$

\section{Discussion}

Our assessment indicates that the documentation and analyses of OECD Sponsorship Testing Programme for Nanomaterials do not support the conclusion that the test guidelines used for regular chemical substances are in the most part suitable for use on nanomaterials. Our analysis of all the published dossiers ${ }^{14}$ with respect to physical-chemical characterization, environmental fate and behavior, as well as ecotoxicological information, reveals that most of the studies were not designed to investigate the validity of the test guidelines. Most contributors to the Sponsorship Programme applied the existing guidelines for chemicals with little, or no, reporting on the test performance when used on nanomaterials. The few studies in the dossiers that do discuss the validity of the tests and explain the modifications that they made to the tests provide substantial points of concern about the general applicability of the OECD test guidelines. Furthermore, our analysis indicates that very 
few studies were carried out for each endpoint, making it hard to generalize about any single technical guideline being generally applicable. It should be acknowledged that the dossiers have made large data set on certain nanomaterials available. However, the added knowledge value appears to be limited, as the reported effect concentrations, as well as added understanding of the fate and behavior of nanomaterials, often replicates what was already known in 2007 and/or stems from studies that, independently of the OECD Sponsorship Programme, have been published in the scientific literature or made available by manufacturers under the European Union's chemical legislation.

The conclusion that "OECD chemical studies show way forward for nanomaterial safety" suggests, that we now have a clear framework for OECD member countries to move forward in the examination of nanomaterials. Our analysis suggests that the published dossiers do not support this conclusion. Rather, they present an incomplete portfolio of nanomaterial toxicity evaluations that are difficult to draw substantive conclusions from. The sponsors' inability to follow the OECD guidance for reporting of key characteristics for ecotoxicity tests of nanomaterials prevents evaluation of the meaningfulness and reproducibility of the generated test results. This in turn hampers the overall ability to learn much from the OECD Sponsorship Programme.

While the programme is not without merit - it has after all facilitated wide international collaboration on nanomaterials testing, and has led to new data being generated - it leaves uncertainties around the applicability of specific testing guidelines to specific nanomaterials, broad testing strategies, and the safe use of the nanomaterials under examination.

There remains a need to systematically evaluate the applicability and interpretation of toxicity assays for nanomaterials, and to develop new methodologies where existing ones fall short. There also remains a need for robust protocols for evaluating the potential risks and safe-use parameters for an increasing array of nanomaterials - many of which lie beyond those tested by the 
OECD program (for instance, catalyst nanomaterials, synthetic mineral nanomaterials such as hydroxyapatite, nano-cellulose). More broadly, there remains a need for protocols that address a growing array of advanced materials that may not fit well into any of the definitions of nanomaterials, yet nevertheless present potential health and environmental risks. ${ }^{37}$ And there is an urgent need for reproducibility tests between different laboratories.

We acknowledge the effort that the OECD WPMN has done in the field of environmental toxicology and fate ${ }^{38,39}$ and we would recommend that a follow-on program is established to supplement this effort building on the lessons of the OECD programme, and systematically addresses identified needs. Ideally, this would be based around well-defined goals and end-points and provide direct funding to qualified research laboratories to ensure valid, rigorous, reproducible and efficient research. Our analysis shows that there indeed is a need to "test the tests" to draw actual conclusions on their applicability to nanomaterials, but this requires a systematic approach to inter-laboratory comparisons, including the "round-robin" testing usually carried out when standardized testing methods are developed and evaluated. For round-robin testing of OECD guidelines it is crucial to test identical materials and to require that specific testing conditions and characterization measures are meticulously implemented if the failures of the OECD sponsorship programme are not to be repeated.

\section{References}

1. OECD 2016. OECD chemical studies show way forward for nanomaterial safety, http://www.oecd.org/chemicalsafety/nanosafety/news-nanomaterial-safety.htm, (Accessed 10 June 2016) 
2. OECD 2016. Sponsorship Programme for the Testing of Manufactured Nanomaterials, http://www.oecd.org/science/nanosafety/sponsorshipprogrammeforthetestingofmanufacture dnanomaterials.htm, (Accessed 10 June 2016)

3. K. Rasmussen, M. González, P. Kearns, J. R. Sintes, F. Rossi and P. Sayre, Regul. Toxicol. Pharmacol., 2016, 74, 147-160.

4. EC JRC 2016. JRC contributes to major OECD breakthrough on nanomaterials safety knowledge, https://ec.europa.eu/jrc/en/news/jrc-contributes-major-oecd-breakthroughnanomaterials-safety-knowledge, (accessed 16-09-2016).

5. OECD 2008. Series on the safety of manufactured nanomaterials number 6 list of manufactured nanomaterials and list of endpoints for phase one of the OECD testing programme. ENV/JM/MONO (2008)13 (2008).

6. OECD 2010. Guidance manual for the testing of manufactured nanomaterials: OECD’ $s$ sponsorship programme; First revision ENV/JM/MONO(2009)/20/REV 2010. http://www.oecd.org/officialdocuments/publicdisplaydocumentpdf/?cote=env/jm/mono(200 9)20/rev\&doclanguage $=$ en, Accessed 10 June 2016

7. OECD 2016. Testing Programme of Manufactured Nanomaterials - Dossiers and Endpoints, http://www.oecd.org/chemicalsafety/nanosafety/dossiers-and-endpoints-testing-programme$\underline{\text { manufactured-nanomaterials.htm, }}$ (Accessed 10 June 2016)

8. OECD 2016. Six years of OECD work on the safety of manufactured nanomaterials, http://www.oecd.org/env/ehs/nanosafety/Nano $\% 20$ Brochure $\% 20$ Sept $\% 202012 \% 20$ for $\% 20$ Website $\% 20 \% 20(2) . p d f$, (Accessed 10 June 2016)

9. OECD 2016. OECD says existing test methods are apt for nanomaterials, https://chemicalwatch.com/12310/oecd-says-existing-test-methods-are-apt-fornanomaterials, (Accessed 10 June 2016) 
10. BIAC 2016. BIAC members, http://biac.org/our-members/, (Accessed 10 June 2016)

11. Chemical Watch 2010. REACH dossier for nanosilver is years away, https://chemicalwatch.com/5985/reach-dossier-for-nanosilver-is-years-away, (Accessed 10 June 2016)

12. Chemical Watch 2011. Nanosilver producers refute German institute's warning, https://chemicalwatch.com/7432/nanosilver-producers-refute-german-institutes-warning, (Accessed 10 June 2016)

13. Center for International Environmental Law, ClientEarth and BUND 2012. Time to act on nanomaterials. http://www.ciel.org/Publications/Nanopatch_EU_Nov2012.pdf Accessed 10 June 2016

14. OECD 2015. Testing Programme of Manufactured Nanomaterials - Dossiers and Endpoints. http://www.oecd.org/chemicalsafety/nanosafety/dossiers-and-endpoints-testing-programmemanufactured-nanomaterials.htm, Accessed 10 June 2016

15. OECD 2016. Silver nanoparticles - Manufactured nanomaterial, http://www.oecd.org/chemicalsafety/nanosafety/silver-nanoparticles-manufacturednanomaterial.htm, (Accessed 10 June 2016)

16. OECD 2016. Endpoint Finder, http://www.oecd.org/env/ehs/nanosafety/Testing\%20Programme $\% 20$ on $\% 20$ Manufactured $\%$ 20Nanomaterials\%20Endpoints.xlsx, (Accessed 10 June 2016)

17. OECD 2016. Fullerenes (C60) - Manufactured nanomaterial, http://www.oecd.org/chemicalsafety/nanosafety/fullerenes-c60manufacturednanomaterial.htm, (Accessed 10 June 2016)

18. N. Shinohara, T. Matsumoto, M. Gamo, A. Miyauchi, S. Endo, Y. Yonezawa and J. Nakanishi, Environ. Sci. Technol., 2009, 43, 948-953. 
19. T. W. K. Fraser, H. C. Reinardy, B. J. Shaw, T. B. Henry and R. D. Handy, Nanotoxicology, $2011, \mathbf{5}, 98-108$.

20. OECD 2016. Single-walled carbon nanotubes (SWCNTs) - Manufactured nanomaterial, http://www.oecd.org/chemicalsafety/nanosafety/single-walled-carbon-nanotubes-swcntsmanufacturednanomaterial.htm, (Accessed 10 June 2016)

21. OECD 2015. Dossier on single-walled carbon nanotubes (SWCNT) - Part 1 - Series on the Safety of Manufactured Nanomaterials No. 50.

http://www.oecd.org/officialdocuments/publicdisplaydocumentpdf/?cote=env/jm/mono $\% 28$ $\underline{2015 \% 2913 / \text { part } 1 \& \text { doclanguage }=\text { en }}$, Accessed 10 June 2016

22. OECD 2015. Dossier on Fullerenes - Part 1 - Series on the Safety of Manufactured Nanomaterials No. 48. http://www.oecd.org/env/ehs/nanosafety/dossieronfullerenes-part1.htm, Accessed 10 June 2016

23. A. D. Maynard, B. K. Ku, M. Emery, M. Stolzenburg and P. H. McMurry, J. Nanoparticle Res., 2007, 9, 85-92.

24. National Academy of Sciences, A Research Strategy for Environmental, Health, and Safety Aspects of Engineered Nanomaterials, the National Academies Press, Washington, DC, 2012.

25. Stone, V. et al. (2009). ENRHES - Engineered nanoparticles: review of health and environmental safety. https://www.researchgate.net/publication/259744602 ENRHES Engineered_nanoparticles_review_of_health_and_environmental_safety, Accessed 10 June 2016.

26. Adams, L.K. et al. Water Sci Technol. 54(11-12), 327-34 (2006)

27. Alvarez P.J.J. Personal communication. 13 September, 2016 
28. OECD 2015. Silicon dioxide - Manufactured nanomaterial.

http://www.oecd.org/chemicalsafety/nanosafety/silicon-dioxide-manufactured-

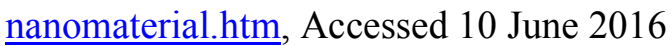

29. ECHA 2010. Practical guide 2: How to report weight of evidence. https://echa.europa.eu/documents/10162/13655/pg_report_weight_of_evidence_en.pdf, Accessed 10 June 2016

30. Klimisch, H.J., Andreae, M., Tillmann, U. Regul Toxicol. Pharm. 25, 1-5 (1997)

31. OECD 1998. Test No. 212: Fish, Short-term Toxicity Test on Embryo and Sac-Fry Stages. http://www.oecd-ilibrary.org/environment/test-no-212-fish-short-term-toxicity-test-onembryo-and-sac-fry-stages 9789264070141-en, Accessed 10 June 2016

32. OECD 2015. Dossier on Titanium dioxide - Part $1 / 2$ - NM 105 Series on the Safety of Manufactured Nanomaterials No. 54. http://www.oecd.org/officialdocuments/publicdisplaydocumentpdf/?cote=env/jm/mono $\% 28$ 2015\%2917/part1/2\&doclanguage=en, Accessed 10 June 2016

33. OECD 2015. Dossier on Titanium dioxide - Part 3 - NM 101 Series on the Safety of Manufactured Nanomaterials No. 54.

http://www.oecd.org/officialdocuments/publicdisplaydocumentpdf/?cote=env/jm/mono $\% 28$ $\underline{2015 \% 2917 / \text { part } 3 \& \text { doclanguage }=\text { en }}$, Accessed 10 June 2016

34. OECD 2015. Dossier on Titanium dioxide - PART 1/1 - NM 105 Series on the Safety of Manufactured Nanomaterials No. 54. http://www.oecd.org/officialdocuments/publicdisplaydocumentpdf/?cote=env/jm/mono $\% 28$ 2015\%2917/part1/1\&doclanguage=en, Accessed 10 June 2016

35. OECD 2012. Guidance on sample preparation and dosimetry for the safety testing of manufactured nanomaterials Series on the Safety of Manufactured Nanomaterials No. 36. 
http://www.oecd.org/officialdocuments/publicdisplaydocumentpdf/?cote=env/jm/mono(201 2) $40 \&$ doclanguage $=$ en, Accessed 10 June 2016

36. Hansen, S.F., Baun, A. Nature Nanotech. 7, 409-411 (2012)

37. Maynard, A.D., Warheit, D.B., Philbert, M.A. Toxicol. Sci. 120(S1), S109-S129 (2011)

38. OECD 2014. Ecotoxicology and environmental fate of manufactured nanomaterials: test guidelines Expert Meeting Report Series on the Safety of Manufactured Nanomaterials No. 40. http://www.oecd.org/officialdocuments/publicdisplaydocumentpdf/?cote=ENV/JM/MONO( 2014)1\&doclanguage=en, Accessed 10 June 2016

39. Kühnel, D., Nickel, C., Sci. Total Environ. 472, 347-353 (2014.).

\section{Figure legends}

Figure 1: Heat map of number of endpoint studies reported for each nanomaterial on environmental fate and behavior and ecotoxicological information. For more details about the data behind the heat map, see Table 2 and 3. 
1

2

3

4

5

6

7

8

9

10

11

12

43

ले 4

当5

96

궉

공

9

20

硰1

23

24

5

26

28

20

31

82

233

34

$\$ 5$

事6

37

38

39

40

41

42

43

44

45

46

47

48

49

50

51

52

53

54

55

56

57

58

59

60 

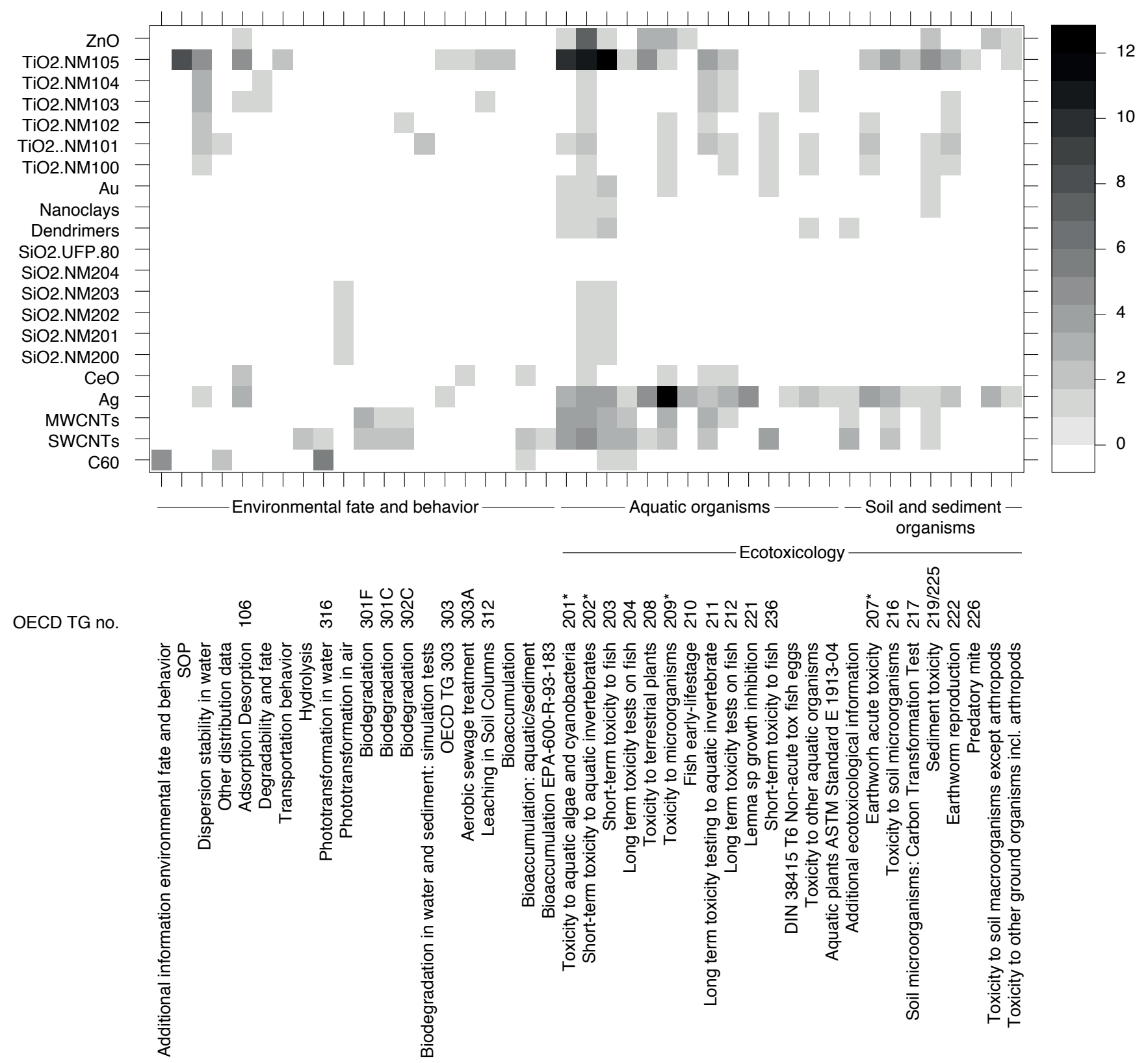